\title{
Identification of a High Affinity Binding Site for Lipo- oligosaccharidic NodRm Factors in the Microsomal Fraction of Medicago Cell Suspension Cultures
}

\author{
Andreas Niebel, ${ }^{1}$ Jean-Jacques Bono, ${ }^{1,2}$ Raoul Ranjeva, ${ }^{2}$ and Julie V. Cullimore ${ }^{1}$ \\ ${ }^{1}$ Laboratoire de Biologie Moléculaire des Relations Plantes-Microorganismes, UMR 215 INRA-CNRS, BP \\ 27, 31326 Castanet-Tolosan Cédex, France; ${ }^{2}$ Signaux et Messages Cellulaires chez les Végétaux, UMR \\ 5546, CNRS-Université Paul Sabatier, 118 Route de Narbonne, 31162 Toulouse Cédex, France. \\ Received 20 May 1996. Accepted 30 October 1996.
}

Protease-sensitive binding sites for a ${ }^{35} \mathrm{~S}$-labeled ligand corresponding to the major lipo-oligosaccharidic symbiotic signal of Rhizobium meliloti (NodRm factor), have been identified in the microsomal fraction of Medicago varia cell suspension culture extracts. Binding was reversible and saturable and tetra- $N$-acetyl chitotetraose was a poor competitor of NodRm binding. Scatchard analysis suggests the presence of a high affinity binding site, termed Nod factor binding site two (NFBS2), with a $K_{d}$ of $1.9 \mathrm{nM}$, and perhaps a second site with an affinity $\left(\mathrm{K}_{\mathrm{d}}\right.$ of $\left.70 \mathrm{nM}\right)$ similar to that of a site (NFBS1) previously characterized in Medicago truncatula root extracts.

Additional keywords: receptors, symbiosis.

The initial stages of the Legume-Rhizobia symbiosis involve a molecular dialogue between the two partners. The plant excretes flavonoids or other secondary metabolites which induce the bacterial genes essential for nodulation (the nod genes). The proteins encoded by these genes then lead to the biosynthesis of lipo-chitooligosaccharidic signals (the Nod factors) which mediate the specific recognition between the two symbiotic partners. Purified Nod factors are able to elicit, at nano-pico molar concentrations the depolarization of root hair membranes, the deformation of root hairs, the division of cortical cells, the activation of specific plant genes, and in certain species the induction of nodules (for reviews see Mylona et al. 1995; Dénarié et al. 1996). Studies using bacterial and plant mutants as well as purified Nod factors suggest that Nod factors may be perceived by specific and possibly multiple receptor mechanisms (Ardourel et al. 1994; Mylona et al. 1995), that remain to be elucidated.

Recently, using a tritiated form of the major Nod factor produced by Rhizobium meliloti, NodRm-IV(Ac,S,C16:2), a specific binding site called Nod factor binding site 1 (NFBS1) has been identified and characterized in a particulate fraction of Medicago root extracts (Bono et al. 1995). The affinity of NFBS1 for NodRm factors, $\left(\mathrm{K}_{\mathrm{d}}=86 \mathrm{nM}\right)$, is, however, low in

Corresponding author: J. V. Cullimore;

E-mail: cullimor@toulouse.inra.fr comparison to the concentrations at which these molecules elicit biological responses (down to $10^{-13} \mathrm{M}$ ). In this paper we describe the use of a ${ }^{35} \mathrm{~S}-\mathrm{NodRm}-\mathrm{IV}(\mathrm{Ac}, \mathrm{S}, \mathrm{C} 16: 2)$ factor, radiolabeled to a high specific activity $(800 \mathrm{Ci} / \mathrm{mmol})$, (Bourdineaud et al. 1995) to search for high affinity NodRm factor binding sites in Medicago varia cell suspension cultures. Cell cultures were used for this work because of their dedifferentiated state, in which many genes are expressed, but also because large amounts of relatively homogeneous material can be produced easily. Cell suspension cultures have additionally been used in other systems to study the perception of microbial signals by plants. Using this simplified experimental model, binding sites have been identified for the Phytophthora megasperma oligopeptide elicitor in parsley cells (Nürnberger et al. 1994) and for a yeast glycopeptide elicitor

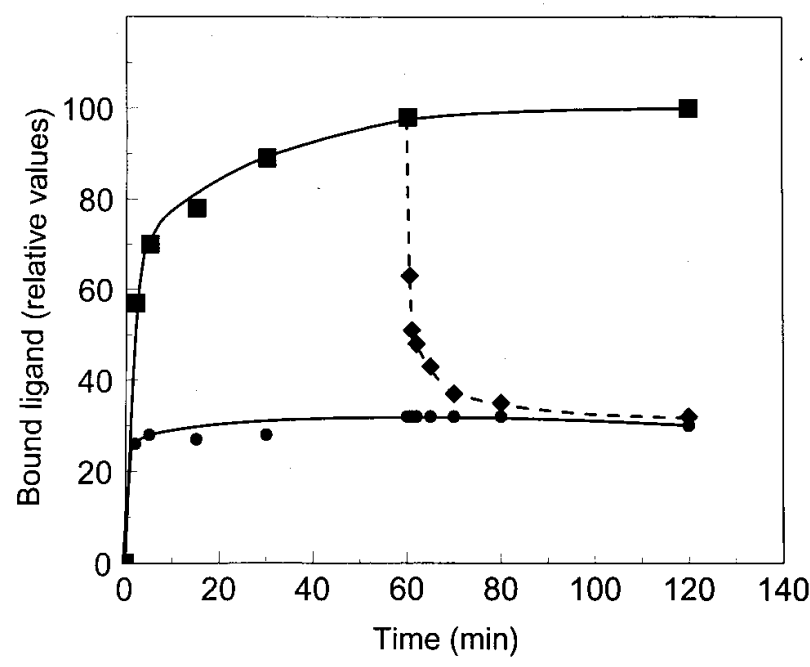

Fig. 1. Kinetics of ${ }^{35} \mathrm{~S}-\mathrm{NodRm}-\mathrm{IV}(\mathrm{Ac}, \mathrm{S}, \mathrm{C} 16: 2)$ binding to the microsomal fraction of Medicago cell culture extracts. Association was measured at $0.5 \mathrm{nM}{ }^{35} \mathrm{~S}-\mathrm{NodRm}-\mathrm{IV}(\mathrm{Ac}, \mathrm{S}, \mathrm{C} 16: 2)$ using $48 \mu \mathrm{g}$ of protein in a total volume of $200 \mu \mathrm{l}$. Dissociation was initiated using $1 \mu \mathrm{M}$ purified, unlabeled NodRm-IV(Ac,S,C16:2). Black squares represent total binding, during the association experiment, black lozenges total binding during the dissociation experiment and black circles non-specific binding. 
and a chitin oligomer elicitor in tomato cells (Basse et al. 1993; Baureithel et al. 1994). The report that Nod factors can stimulate progression of $M$. sativa cell suspension cultures through the cell cycle and induce gene expression (Savouré et al. 1994), suggests in addition that NodRm factors are perceived by Medicago cells in culture.

Extracts from $M$. varia cell suspensions in the stationary phase were prepared and fractionated using differential centrifugations according to Bono et al. (1995) and binding assays were then performed with the ${ }^{35} \mathrm{~S}$-labeled NodRm factor. As shown in Table 1, binding activity was found in all three fractions assayed, but $65 \%$ of the overall activity was concentrated in the $100,000 \times g$ fraction (the microsomal fraction). Further characterization of the binding activity was thus performed using this microsomal fraction. Binding of the radiolabeled NodRm factor to the microsomal fraction proceeded in a time dependent manner (Fig. 1). Half maximal binding was already achieved by approximately $2 \mathrm{~min}$ and an apparent equilibrium was reached after about $1 \mathrm{~h}$ at $0^{\circ} \mathrm{C}$. The specific binding activity represented about $70 \%$ of the total binding. Addition of an excess of unlabeled NodRm factor led to the loss of specifically bound radioactivity, demonstrating that the binding was reversible. The dissociation proceeded even more rapidly. Indeed, half of the specific binding activity was lost within $30 \mathrm{~s}$ and a total displacement was achieved after 15 $\min$.

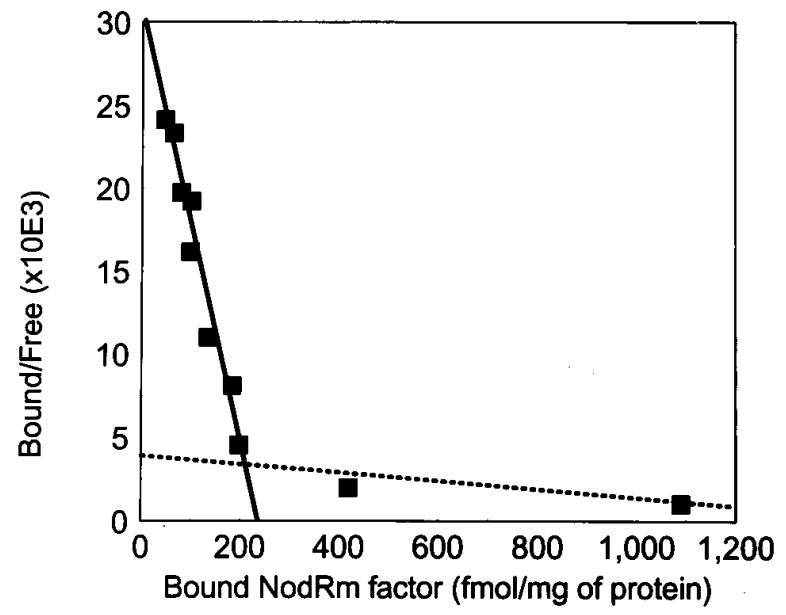

Fig. 2. Scatchard plot of a typical equilibrium binding experiment using $0.5 \mathrm{nM}{ }^{35} \mathrm{~S}-\mathrm{NodRm}$-IV(Ac,S,C16:2) and different concentrations of purified, unlabeled NodRm-IV(Ac,S,C16:2).
The Scatchard analysis of a typical equilibrium binding experiment can be seen in Figure 2. The non-linearity of the plot may be interpreted in two ways. Firstly, it may indicate the presence of two binding sites; a high affinity binding site with an equilibrium binding constant $\left(\mathrm{K}_{\mathrm{d}}\right)$ of $1.9 \mathrm{nM}$ and a maximal binding capacity $\left(\mathrm{B}_{\max }\right)$ of 0.2 pmol per $\mathrm{mg}$ of protein and a lower affinity site with a $K_{d}$ of about $70 \mathrm{nM}$ and a $B_{\max }$ of approximately 1.3 pmol per $\mathrm{mg}$ of protein. (Note that the presence of the high and lower affinity binding has been confirmed in other experiments). The lower affinity binding site would thus have an affinity for NodRm close to that of NFBS1 $\left(\mathrm{K}_{\mathrm{d}}=86 \mathrm{nM}\right)$ (Bono et al. 1995). Secondly the plot could indicate negative cooperativity between a single type of binding sites. However further analysis of the kinetics of ligand dissociation is consistent with the presence of two sites and we thus favour the former interpretation. The higher affinity site, with a $K_{d}$ of almost two orders of magnitude lower than that of NFBS1, will be referred to as Nod factor binding site 2 (NFBS2). It is clear that the high specific activity of the ${ }^{35} \mathrm{~S}$-labeled ligand has enabled the identification and characterization of this site.

Figure 3 shows that tetra-N-acetyl-chitotetraose is a very

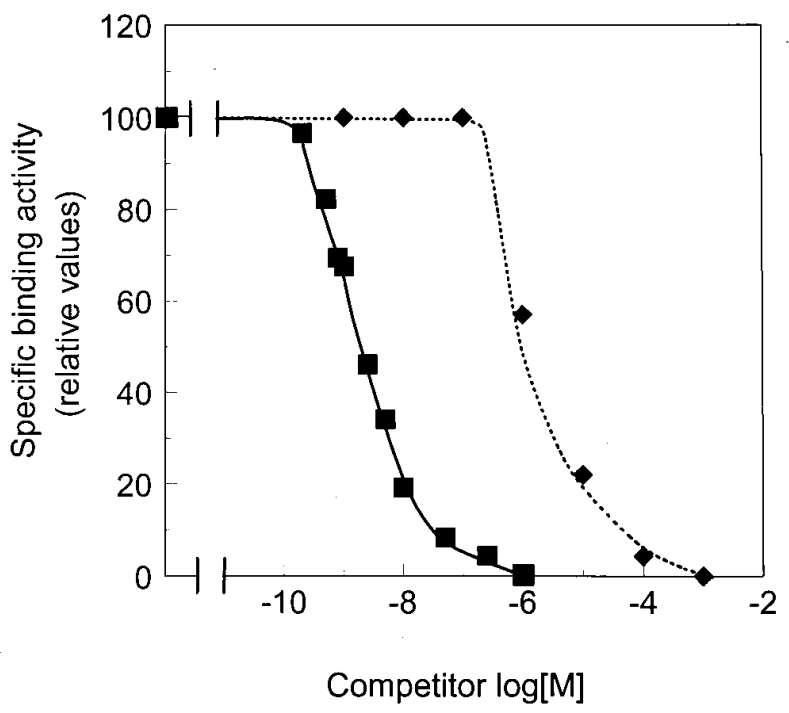

Fig. 3. Competitive inhibition of ${ }^{35} \mathrm{~S}-\mathrm{NodRm}-\mathrm{IV}(\mathrm{Ac}, \mathrm{S}, \mathrm{C} 16: 2)$ binding at increasing concentrations of tetra-N-acetyl-chitotetraose (black lozenges) and purified, unlabelled NodRm-IV (Ac, S,C16:2) (black squares).

Table 1. Comparison of binding activities of ${ }^{35} \mathrm{~S}-\mathrm{NodRm}-\mathrm{IV}(\mathrm{Ac}, \mathrm{S}, \mathrm{C} 16: 2)$ in particulate fractions, obtained at different centrifugal forces, ${ }^{\mathrm{a}}$ of Medicago varia cell suspension culture extracts

\begin{tabular}{lccc}
\hline Centrifugal force & $\mathbf{3 , 0 0 0} \times \mathbf{g}$ & $\mathbf{1 0 , 0 0 0} \times \mathbf{g}$ & $\mathbf{1 0 0 , 0 0 0} \times \mathbf{g}$ \\
\hline Specific binding activity for the overall fraction (fmol) & 102 & 1,240 & 2,560 \\
Specific binding activity (fmol/mg of protein) & 3.4 & 18 & 29 \\
\hline
\end{tabular}

${ }^{a}$ The preparation of the fractions and the binding assays were as described by Bono et al. (1995). Forty-eight micrograms of proteins was then incubated with radiolabeled ligand at a final concentration of $0.5 \mathrm{nM}$, for $1 \mathrm{~h}$ at $0^{\circ} \mathrm{C}$. Nonspecific binding was determined in the presence of $1 \mu \mathrm{M}$ biologically produced NodRm factor. The incubations were performed in 96-well microtiter plates (Nunc). At the end of the incubation, the samples were filtered through filtermats ( $1.5 \mu \mathrm{m}$ sieve) with a Skatron Cell Harvester (Skatron Inc, Transby, Norway). Each filterdisk (9 mm diameter) was washed with $5 \mathrm{ml}$ of $25 \mathrm{mM}$ Tris- $\mathrm{HCl}$ buffer, $\mathrm{pH} 7.0$, containing $1 \mathrm{mM} \mathrm{CaCl}_{2}$ and $1 \mathrm{mM} \mathrm{MgCl}_{2}$, dried, transferred into scintillation vials and the radioactivity was measured by scintillation spectrometry. These conditions were used in subsequent experiments unless otherwise specified. Radioligand binding experiments were processed with the computer program EBDA (Equilibrium Binding Data Analysis, McPherson, 1985). 
poor competitor of ${ }^{35} \mathrm{~S}-\mathrm{NodRm}-\mathrm{IV}(\mathrm{Ac}, \mathrm{S}, \mathrm{C} 16: 2)$ binding since the concentration needed to inhibit $50 \%$ of the ligand binding $\left(\mathrm{IC}_{50}\right)$ is about a thousand-fold higher than for unlabeled NodRm factors. This result suggests that NFBS2 is specific for lipo-oligosaccharides and, in this respect, NFBS2 is different from the chitin oligomer binding sites identified in microsomes of tomato and rice cell cultures (Shibuya et al. 1993; Baureithel et al. 1994).

To check the protease sensitivity of NFBS1 and NFBS2 in cell suspension culture extracts, aliquots of microsomes containing $48 \mu \mathrm{g}$ of protein were incubated with $48 \mu \mathrm{g}$ of proteinase $\mathrm{K}$ for $1 \mathrm{~h}$ at $37^{\circ} \mathrm{C}$. As a control the proteinase $\mathrm{K}$ was previously heat denatured at $100^{\circ} \mathrm{C}$ for $10 \mathrm{~min}$. Binding was then carried out at two concentrations of ${ }^{35} \mathrm{~S}-\mathrm{NodRm}$ IV(Ac,S,C16:2), 0.5 and $10 \mathrm{nM}$. In both cases, over $95 \%$ of the specific binding activity was lost in the protease-treated samples, while controls retained $75 \%$ of the initial binding activity, thereby suggesting that both binding sites could be membrane-located, proteinaceous structures.

Nod factors have been shown to elicit biological responses at concentrations as low as $10^{-11} \mathrm{M}$ or $10^{-13} \mathrm{M}$ (Lerouge et al. 1990; Journet et al. 1994; Kurkdjian 1995; Felle et al. 1995). A quantification of these biological responses has however only been reported once, by Felle and co-authors (1995), who have measured the membrane depolarization of root hairs at different NodRm factor concentrations. They report half of the maximal depolarization at a NodRm concentration of 1 to 2 $\mathrm{nM}$, which is similar to the $\mathrm{K}_{\mathrm{d}}$ measured for NFBS2. Such a $\mathrm{K}_{\mathrm{d}}$ value seems consistent with biological responses to NodRm factors observed at concentrations down to $10^{-11} \mathrm{M}$, and one may thus speculate that NFBS2 could be involved in mediating some biological responses elicited by NodRm factors. However, in order to evaluate the potential role of this site in the symbiosis it needs to be established whether the site exists in roots. In addition, as the sulfate, $O$-acetate and the structure of the fatty acid of NodRm factors are important for biological activities (Ardourel et al. 1994; Journet et al. 1994) the specificity of the site needs to be determined.

In conclusion we present evidence for the existence of a microsomally located, protease-sensitive Nod factor binding site in Medicago cell suspension cultures (NFBS2) exhibiting a $\mathrm{K}_{\mathrm{d}}$ in the nanomolar range. This result suggests that lipooligosaccharides, like other microbial oligosaccharidic signals (Cheong and Hahn 1991; Cosio et al. 1992; Yoshikawa and Sugimoto 1993; Shibuya et al. 1993; Baureithel et al. 1994; Boller 1995; Mithöfer et al. 1996), may be perceived by membrane-located receptor proteins. Whether the new site is important in the symbiosis however, remains to be determined.

\section{ACKNOWLEDGMENTS}

We wish to thank Michèle Axelos for generously sharing with them her rich experience in cell suspension cultures and for maintaining the Medicago varia cell culture line. We are also grateful to Mireille Chabaud for originally starting and maintaining the cell suspension line. Andreas Niebel gratefully acknowledges EMBO for a long term postdoctoral fellowship. This work was funded in part by the European Communities Biotechnology Programme, as part of the Project of Technological Priority 1993-1996, and by the program Human Capital and Mobility (contract CHRX-CT94-0656). All the authors are members of the IFR 40 "Signalisation et Biotechnologie Végétale".

\section{LITERATURE CITED}

Ardourel, M., Demont, N., Debellé, F., Maillet, F., de Billy, F., Promé, J. C., Dénarié, J., and Truchet, G. 1994. Rhizobium meliloti lipooligosaccharide nodulation factors: different structural requirements for bacterial entry into target root hair cells and induction of plant symbiotic developmental responses. Plant Cell 6:1357-1374.

Basse, C. W., Fath, A., and Boller, T. 1993. High affinity binding of glycopeptide elicitor to tomato cells and microsomal membranes and displacement by specific glycan suppressors. J. Biol. Chem. 268:14724-14731.

Baureithel, K., Felix, G., and Boller, T. 1994. Specific high affinity binding of chitin fragments to tomato cells and membranes. J. Biol. Chem. 264:17931-17938.

Boller, T., 1995. Chemoperception of microbial signals in plant cells. Annu. Rev. Plant Physiol. Plant Mol. Biol. 46:189-214.

Bono, J.-J., Riond, J., Nicolaou, K. C., Bockovich, N. J., Estevez, V. A., Cullimore, J. V., and Ranjeva, R. 1995. Characterisation of a binding site for chemically-synthesized lipo-oligosaccharidic NodRm factors in particulate fractions prepared from roots. Plant J. 7:252-260.

Bourdineaud, J. P., Bono, J. J., Ranjeva, R., and Cullimore, J. 1995. Enzymatic radiolabelling to a high specific activity of legume lipooligosaccharidic nodulation factors from Rhizobium meliloti. Biochem. J. 306:259-264.

Cheong, J. J., and Hahn, M. G. 1991. A specific, high-affinity binding site for the hepta-glucoside elicitor exists in soybean membranes. Plant Cell 3:137-147.

Cosio, E. G., Frey, T., and Ebel, J. 1992. Identification of a high-affinity binding protein for hepta-ß-glucoside phytoalexin elicitor in soybean. Eur. J. Biochem. 204:1115-1123.

Dénarié, J., Debellé, F., and Promé, J. C. 1996. Rhizobium lipochitooligosaccharide nodulation factors: Signalling molecules mediating recognition and morphogenesis. Annu. Rev. Biochem. 65:503535.

Felle, H., F., Kondorosi, E., Kondorosi, A., and Schultze, M. 1995. Nod signal induced plasma membrane potential changes in alfalfa root hairs are differentially sensitive to structural modifications of the lipochitooligosaccharide. Plant J. 7:939-947.

Journet, E. P., Pichon, M., Dedieu, A., de Billy, F., Truchet, G., and Barker, D. G. 1994. Rhizobium meliloti Nod factors elicit cell-specific transcription of the ENOD12 gene in transgenic alfalfa. Plant J. 6:241249.

Kurkdjian, A. C. 1995. Role of the differentiation of root epidermal cells in Nod factor (from Rhizobium meliloti)-induced root-hair depolarization of Medicago sativa. Plant Physiol. 107:783-790.

Lerouge, P., Roche, P., Faucher, C., Maillet, F., Truchet, G., Promé, J. C., and Dénarié, J. 1990. Symbiotic host-specificity of Rhizobium meliloti is determined by a sulphated and acylated glucosamine oligosaccharide signal. Nature 344:781-784.

McPherson, G. A. 1985. Analysis of radioligand binding experiments: A collection of computer programs for the IBM PC. J. Pharmacol. Meths. 14: 213-228.

Mithöfer, A., Lottspeich, F., and Ebel, J. 1996. One-step purification of the $\beta$-glucan elicitor-binding protein from soybean (Glycine $\max \mathrm{L}$.) roots and characterization of an anti-peptide antiserum. FEBS Lett. 381:203-207.

Mylona, P., Pawlowski, K., and Bisseling, T. 1995. Symbiotic nitrogen fixation. Plant Cell 7:7869-7885.

Nürnberger, T., Nennstiel, D., Jabs, D., Sacks, W. R., Hahlbrock, K., and Scheel, D. 1994. High affinity binding of a fungal oligopeptide elicitor to parsley plasma membranes triggers multiple defense responses. Cell 78:449-460.

Savouré, A., Magyar, Z., Pierre, M., Brown, S., Schultze, M., Dudits, D., Kondorosi, A., and Kondorosi, E. 1994. Activation of the cell cycle machinery and the isoflavonoid biosynthesis pathway by active Rhizobium meliloti Nod signal molecules in Medicago microcallus suspensions. EMBO J. 13:1093-1102.

Shibuya, N., Kaku, H., Kuchitsu, K., and Mallarik, M. J. 1993. Identification of a novel high affinity binding site for $\mathrm{N}$-acetylchitooligosaccharide elicitor in the membrane fraction from suspension cultured rice cells. FEBS Lett. 329:75-78.

Yoshikawa, M., and Sugimoto, K. 1993. A specific binding site on soybean membranes for a phytoalexin elicitor released from fungal cell walls by $\beta$-1-3-endoglucanase. Plant Cell Physiol. 34:1229-1237. 